\title{
SPLENIC MECHANISMS IN THE PATHOGENESIS OF ANAEMIA
}

\author{
A. J. BOWDLER, M.D., B.Sc., M.R.C.P. \\ T. A. J. Prankerd, M.D., F.R.C.P. \\ from the M.R.C. Research Group in Haemolytic Diseases, \\ University College Hospital Medical School, \\ London, W.C.1.
}

\begin{abstract}
ANAEMIA is not infrequently accompanied by enlargement of the spleen, and in some instances, as in the haemorrhagic anaemia of portal hypertension, it is clear that both splenomegaly and anaemia arise from a common factor. The reasons for the relationship of splenomegaly and anaemia are less easily discerned in other conditions, such as pernicious anaemia and iron deficiency states. In a third group there is evidence for the dependance of the anaemia on the presence of the enlarged spleen, and it is in these that the investigation of the spleen is most significant in view of the possibility of correcting the anaemia by splenectomy.

The role of the spleen in producing anaemia has been frequently discussed in terms of two principal mechanisms, the first being the depression of red cell production, and the second the direat destruction of red cells during their passage through the organ. Recent work has tended to focus less attention on the possible dyshaemopoietic influence of the spleen and has emphasized the complexity of the relationship between the organ and the circulating red cell.
\end{abstract}

\section{Splenomegaly and Erythropoiesis}

The possibility of marrow depression arising from a presumptive humoral influence of the spleen has been frequently considered, for instance by Moeschlin (1956), Cohen, Gardner and Barnett (1961a and b) and Dameshek (1960). Motulsky, Casserd, Giblett, Broun and Finch (1958), in dismissing such a mechanism, stated that they had never obtained satisfactory evidence for it, but Wetherley-Mein, Jones and Pullan (1961) have presented radio-iron studies of patients with myeloid metaplasia before and after splenectomy which were consistent with an improvement in marrow function following removal of the spleen.

The problem is an especially difficult one to evaluate: marrow depression in the presence of splenomegaly, as in lymphomata, acute and chronic leukaemias, and the lipidoses, may be due to other effects of the disease, especially in the presence of marrow infiltration. Further, red cell output has to be assessed in relation to red cell lifespan, which may also alter after splenectomy, and the marrow response to a shortened red cell lifespan is only imperfectly known. A frequently quoted figure for red cell production in states of chronic haemolysis is six to eight times the normal rate (Crosby and Akeroyd, 1952). However, Mollison (1956) found output as high as 12 times normal in a patient with paroxysmal nocturnal haemoglobinuria, and we have investigated a man of 18 years with antiglobulin-positive autoimmune haemolytic disease who maintained a haematocrit of $20.5 \%$ despite a mean red cell lifespano of 3.5 days, indicating a red cell output of 16 times normal. Following splenectomy, the spleen was found to weigh more than $700 \mathrm{~g}$. If is thus clear that splenomegaly per se is in sufficient to impair eryithropoiesis, although this does not necessanily exclude the possibility of a depressant effect by the spleen in other conditions.

\section{Splenic Destruction in situ}

The pulp of the spleen consists of venous sinuses between which run the pulp cords of Billroth. The controversy over the direction and degree of the blood flow through the cords is still unresolved, but in man the circulation is probably of the mixed variety, both open and closed channels being present (Weiss, 1959) although the direct sinusoidal pathway is thought to predominate (Prankerd, 1963). Barnett and Lewis (1961) have pointed out that the red cells may sometimes pass through what is functionally a mesenchymal mass, honeycombed with ohannels lined by reticular cells, which brings the blood cells into close contact with the macrophage system. The structure is therefore well adapted to be a site of active erythrophagocytosis.

In normal circumstances in man, the spleen plays only a small part in the destruction of red cells, sharing this function with other components of the macrophage system (Prankerd, 1963). In many abnormal circum- 
stances, however, the spleen may become the principal site for the destruction of red cells, as shown both by the accumulation of iron in the tissues, and by the progressive deposition of chromium-51 in the spleen after the intravenous injection of labelled red cells (Jandl, Greenberg, Yonemoto and Castle, 1956; Hughes Jones and Szur, 1957; McCurdy and Rath, 1958). Such a situation may result from abnormalities of the endogenous red cells, as in hereditary spherocytosis or elliptocy.tosis, or an abnormality mainly in the spleen itself such that normal transfused cells may also be destroyed even in the absence of demonstrable antibodies, a situation sometimes encountered in thalassaemia major.

The concept has arisen of "splenopathic anaemia", for instance in leukaemia, in which the enlarged spleen, by reason of its increased size, exerts a deleterious and destructive effect on the red cell (Dameshek and Gunz, 1959). It is certainly true that massive splenomegaly is frequently accompanied by a reduction in the red cell lifespan, but this is not necessarily so, at least within the limits that can be assessed by the chromium-51 method (Bowdler, 1965). Further, even when shortened survival is present, this is not necessarily corrected by splenectomy, and a spleen of large size cannot in all instances be held to imply excessive destruction within the organ.

\section{Red Cell Pooling}

In certain haemolytic states the spleen has a high red cell content, sometimes representing a substantial fraction of the total red cell mass. Such intrasplenic red cells might be considered irreversibly trapped in the organ until destroyed in situ. Alternatively, they might be regarded as a population exchanging with the red cells of the general circulation. Thirdly, since these are not mutually exclusive possibilities, some cells might be irreversibly trapped while others could still return to the extrasplenic circulation. For some authors the term "sequestration" implies cell trapping by the spleen with subsequent destruction of the cells in the organ, buit in general it is preferable to keep the difference between pooling and destruction quite distinct as the two processes are not necessarily associated.

The spleen may contain a substantial fraction of the total red cells of the body despite the absence of progressive anaemia and this must imply either prolonged survival of the cells before destruction by the organ, with a relatively slow rate of entry of cells to the pool, or a balanced interchange between the pool and the general circulation, in which case the rate of entry could be much greater. This arises from the fact that in a steady state, any irreversible loss of cells from the general circulation must be balanced by an equivalent release of new cells from the bone marrow, which imposes a constraint on the maximum rate of loss under such conditions.

Conditions of rapid interchange between the general circulation and the splenic pool can be demonstrated either by following the secondary rise in splenic radioactivity after the intravenous injection of isotope-labelled cells by means of a scintillation counter (Motulsky, Casserd and Giblett, 1956; Harris, McAlister and Prankerd, 1958) or by estimating the associated fall in the blood radioactivity (Motulsky and others, 1958). Simultaneous measurements of blood and spleen activity have been found to produce patterns consistent with the concept of two-pool interchange. Evidence for irreversible pooling is more difficult to obtain, buit suoh a possibility may sometimes be inferred (Bowdler, 1962), and in some conditions it is olear that both interchanging and irreversible pools are present together.

Splenic pooling of red cells has been shown in hereditary spherocytosis, autoimmune haemolytic disease, chronic myeloid leukaemia, thalassaemia major, myeloid metaplasia, pernicious anaemia, Hodgkin's disease and in sicklecell disease when splenomegaly is present, although not every case of these diseases will show the phenomenon. Pooling may also occur in the normal spleen when abnormal cells are introduced into the circulation; Harris and others (1958) demonstrated this with naturally occurring and artificial spherocytes and with antibody-coated cells, whille Bowdler (1962) found it to occur with the cells of a spleneotomized thalassaemic donor. In many instances in which pooling occurs there are abnormalities in the shape or volume of the red cells, which may affect the rate of transit of such cells at the level of the communications between the splenic cords and the sinuses. However, gross changes in the cells are not necessarily present, and more subtle alterations of the cell surface, such as the depletion of lipid (Harris, McAlister and Prankerd, 1957) or blockade of sulphydryl groups (Jacobs and Jandl, 1962) are also effective.

It is clear then that in many conditions, the red cells may spend intermittent periods packed within the pulp of the spleen, a situation which 
in many respects can be regarded as metabolically disadvantageous, as shown by the low $\mathrm{pH}$ and high lactic acid content of the splenic pulp (Murphy, 1962). The possibly deleterious effects of such an environment have principally been discussed in relation to the heredilary spherocyte (Young, 1955; Emerson, Shen, Ham, Fleming and Castle, 1956; Prankerd, 1960) and the relevance of this to other conditions remains to be proved. The H.S. cell has widely been considered to acquire a residuum of damage during repeated incubations in the splenic pool, which ultimately renders it liable to removal by the reticuloend othelial system. In one subject, however, who showed marked sphering of cells and a large splenic pool of red cells in the course of an autoimmune haemolytic anaemia, there was found not only destruction of red cells in the spleen with local storage of the contained isotope, but also evidence of haemolysis with release of the isotope to secondary storage in extrasplenic sites, thus suggesting either that there is more than one mode of red cell destruction in such a spleen, or that the haemolytic capacity of the spleen can exceed the capacity of the organ for storing the produats of red cell destruction (Bowdler, 1962). Recently, Rifkind (1964) has studied the spleen by electron microscopy in rabbits in which Heinz body anaemia had been induced by phenylhydrazine. Evidence was obtained in this instance also for two modes of eryithrocyite destruction, the bulk of the cells being destroyed by erythrophagocytosis in the cords, while a smaller proportion was destroyed by intravascular lysis in the sinusoids.

\section{Antibody Production}

The recognition of the role of the lymphocyte and the plasma cell in the synthesis of immunoglobulins would imply a significant function for the spleen in antibody production. In the rat, it has been shown experimentally that the formation of antibody after the intravenous injection of antigen is initiated by the spleen, while such precedence does not exist when the antigen is introduced by other routes (Rowley, 1950a). Taliaferro and Taliaferro (1952) have studied the production of haemolysin to sheep red cells in rabbits, and found the spleen important in the response to the initial and second doses of antigen, but less important subsequently. In man, Rowley (1950b) has found a marked inadequacy in antibody response to injected sheep red cells in splenectomized subjects. There is thus a strong possibility that the spleen may be a significant site for the production of anti-erythrocyte antibodies in autoimmune haemolytic disease. Such an hypothesis would account for the reduction in antiglobulin titre of the red cells found in many cases of this disease after splenectomy. It would further help to explain the improvement after splenectomy in cases in which excessive deposition of chromium-51 from labelled red cells in the spleen is not prominent, and in which it may be supposed that some factor ather than local destruction of cells in the organ must be operating (Bowdler, 1965).

In this context, it may further be conjectured that the vascular architecture of the spleen may, by producing the close apposition of the target red cell with the antibody producing cells, lead effectively to the coatting of the former while repeatedly stimulating the latter.

\section{Dilution Anaemia}

A further mechanism by which anaemia may arise in the presence of an enlarged spleen has recently been recognised. An investigation of the anaemia accompanying crypitogenic splenomegaly in Chinese subjects by MoFadzean, Todd and Tsang (1958a and b) showed a haemolytic process which could be corrected by splenectomy, but in some cases the haemo globin level was further lowered by expansiono of the plasma volume, which thus effectively? diluted the red cell mass. The plasma volume could, however, be reduced by splenectomy, though less effectively when there was associated hepatic cirrhosis.

Similar expansion of the plasma volume with reduction in the level of haemoglobin in the circulating blood was found in a case of Gaucher's disease by Bowdler (1963), and here too there was a reduction in the plasma volume after splenectomy of such a degree that although the red cell mass also declined, the relative volume of the red cells increased. In this instance, there was no significant change in the red cell lifespan and correction of the anaemia could be ascribed entirely to the volume changes. Similar observations have also been made in cases of myeloid metaplasia and chronic myeloid leukaemia (Bowdler, 1965).

Weinstein (1964) studied five cases of simple splenic hyperplasia, two of them associated with rheumatoid disease. All patients showed a rise in the venous haematocrit after splenectomy, and in none was there a rise in the total mass of the red cells. Contraction of the plasma volume was proved in three cases, and inferred in the remainder.

The mechanism of the expansion of the 
plasma volume in these cases is not entirely understood. One possible mechanism is that the vascular space requiring to be filled with blood may be excessive in the presence of a large spleen, and that the marrow in these conditions is insufficiently active to be able to supply sufficient red cells for this to be possible. Consequently, the plasma expands in compensation for the relative inadequacy of the available red cell mass. The tendency of the spleen to concentrate red cells so as to produce a high intrasplenic ratio of cells to plasma, as shown by Verel (1954), Rothschild, Bauman, Yalow and Berson (1954) and others, would make splenic enlargement especially significant as a drain on the available red cell mass. However, this cannot be a complete explanation, since correction of the anaemia may be delayed for several weeks after splenectomy, so that some extrasplenic adjustment of the plasma volume must take place. Whether this depends on the late changes in the vasculature of the splenic bed after operation, as suggested by McFadzean and others (1958b), or whether there is a secondary alteration in the plasma oncotic pressure, as inferred by Weinstein (1964), remains to be investigated.

\section{Discussion}

There is now considerable evidence that the relationship between the spleen and the red cell is not limited to erythrophagocytic destruction. In some respects this has complicated the problem of deciding on the advisability of splenectomv in the individual case. In a few instances, disease involving the spleen is sufficiently constant in its response to removal of the spleen for the decision to be reached withou't difficulty: there are, for instance, seldom any doubts as to the advisability of operation in a case of herediitary spherocytosis. Much more commonly, there is the need to assess the possible benefit of operation in an individual case, and where this has essentially to be assessed in relation to the probable effect on anaemia, the mechanisms outlined must clearly be considered.

For more than ten years, since the method was described by Gray and Sterling (1950), it has been possible to estimate the red cell lifespan by the chromium-51 labelling technique, and this can be combined with surface counting to provide an indication of the principal sites of cell destruction, especially in relation to whether the spleen is actively destroying red cells. When positive, such indications are usually helpful, but it is clear that splenectomy may also be useful in cases in which this is not indicated by the accumulation of isotope to any marked degree by the spleen.

Firstly, this may occur when the anaemia is due to the diluting effects of a high plasma volume. It is therefore useful to measure the red cell mass as part of the chromium-51 study, and to confirm the findings by an estimate of the plasma volume, for instance by the use of ${ }^{131}$ I-labelled human serum albumin. The finding of pooling of red cells in the spleen, as indicated by surface counting over the organ 'together with interval estimates of the red cell mass, also provides some indication of ineffective distribution of the available red cells.

Secondly, relief of anaemia may sometimes be obtained by spleneotomy even when isotope deposition has been prominent in the liver as well as the spleen, and when no dilution effect is operating. The reason for this is conjectural, but presumably some other function of the spleen, such as its facility for producing antibodies, may have been critical in the production of the anaemia. It remains true at the present time, therefore, that the information required for a strictly reasoned assessment of the outcome of splenectomy on the severity of an associated anaemia is in many cases still inaccessible.

\section{Summary}

An outline has been presented of the mechanisms by which the spleen may oontribute to the production of anaemia. These are present to different degrees in individual cases, and consequently the assessment of the importance of the specific factors in any one case may only be possible retrospectively, if at all. The assistance which can be obtained by available methods of isotope study of red cell destruction is considered and the limitations of the techniques indicated.

\section{REFERENCES}

BARNeTt, C. H., and LewiS, O. H. (1961): in "Recent Advances in Anatomy", by Goldby, F., and Harrison, R. J. 2nd Series. p. 388. London: J. \& A. Churchill.

BowDler, A. J. (1962): Theoretical Considerations Concerning Measurement of the Splenic Red Cell Pool, Clin. Sci., 23, 182.

BowDler, A. J. (1963): Dilution Anemia Corrected by Splenectomy in Gaucher's Disease, Ann. intern. Med., 58, 664.

BOWDLER, A. J. (1965): unpublished observations.

COHEN, P., GARDNER, F. H., and BARNETT, G. $O$. (1961a): Reclassification of the Thrombocytopenias by the $\mathrm{Cr}^{51}$-Labeling Method for Measuring Platelet Life Span, New Engl. J. Med., 264, 1294.

Cohen, P., Gardner, F. H., and Barnetr, G. O. (1961b): Reclassification of the Thrombocytopenias 
by the $\mathrm{Cr}^{51}$-Labeling Method for Measuring Platelet Life Span (Concluded), New Engl. J. Med., 264, 1350.

Crosby, W. H., and Akeroyd, J. H. (1952): The Limit of Hemoglobin Synthesis in Hereditary Hemolytic Anemia, Amer. J. Med., 13, 273.

DAMESHEK, W. (1960): Controversy in Idiopathic Thrombocytopenic Purpura, J. Amer. med. Ass., 173, 1025.

DAMESHEK, W., and Gunz, F. (1958): "Leukemia", New York and London: Grune and Stratton.

Emerson, C. P., Shen, S. C., Ham, T. H., Fleming, E. M., and CASTLE, W. B. (1956): Studies on the Destruction of Red Blood Cells. IX Quantitative Methods for Determining the Osmotic and Mechanical Fragility of Red Cells in the Peripheral Blood and Splenic Pulp; the Mechanism of Increased Hemolysis in Hereditary Spherocytosis (Congenital Hemolytic Jaundice) as Related to the Functions of the Spleen, Arch. intern. Med., 97, 1.

Gray, S. J., and STERLING, K. (1950): The Tagging of Red Cells and Plasma Proteins with Radioactive Chromium, J. clin. Invest., 29, 1604.

HARris, I. M., MCAlister, J. M., and Prankerd, T. A. J. (1957): The Relationship of Abnormal Red Cells to the Normal Spleen, Clin. Sci., 16, 223.

Harris, I. M., McAlister, J., and Prankerd, T. A. J. (1958): Splenomegaly and the Circulating Red Cell, Brit. J. Haemat., 4, 97.

Hughes JONES, N. C., and SzUR, L. (1957): Determination of the Sites of Red Cell Destruction using $\mathrm{Cr}^{51}$-Labelled Cells, Brit. J. Haemat., 3, 320.

JACOBS, H. S., and JANDL, J. H. (1962): Effects of Sulfhydryl Inhibition on Red Blood Cells. II. Studies in Vivo, J. clin. Invest., 41, 1514.

JaNDL, J. H., GREENBERG, IM. S. Y., YoNemOTO, R. H., and Castle, W. B. (1956): Clinical Determination of the Sites of Red Cell Sequestration in Hemolytic Anemias, J. clin. Invest., 35, 843.

MCCURDY, P. R., and RATH, C. E. (1958): Splenectom $r$ in Hemolytic Anemia. Results Predicted by Body' Scanning after Injection of $\mathrm{Cr}^{51}$ Tagged Red Cells, New Engl. J. Med., 259, 459.

MoFadzeIN, A. J. S., TodD, D., and Tsang, K. C. (1958a): Observations on the Anemia of Cryptogenetic Splenomegaly. I. Hemolysis, Blood, 13, 513.

MoFadzean, A. J. S., TodD, D., and Tsang, K. C. (1958b): Observations on the Anemia of Cryptogenetic Splenomegaly. II. Expansion of the Plasma Volume, Blood, 13, 524.

Moeschlin, S. (1956): Physiopathologie des Hypersplenismus, Helv. Med. Acta, 23, 416.
Mollison, P. J. (1956): "Blood Transfusion in Clinical Medicine", 2nd Edition, p. 149, Oxford: Blackwells.

Motulsky, A. G., Casserd, F., and Giblett, E. (1956): In Vivo Measurement of the Splenic Circulation: a Rapid Method of Demonstration of Red Cell Sequestration, J. clin. Invest., 35, 725.

Motulsky, A. G., Casserd, F., Giblett, E. R., Broun, G. O., and FinCH, C. A. (1958): Anemia and the Spleen, New Engl. J. Med., 259, 1164.

MurPHY, J. R. (1962): Erythrocyte Metabolism. III. Relationship of Energy Metabolism and Serum Factors to the Osmotic Fragility Following Incubation, J. lab. Clin. Med., 60, 32.

Prankerd, T. A. J. (1960): Studies on the Pathogenesis of Haemolysis in Hereditary Spherocytosis, Quart. J. Med., N.S., 29, 199.

Prankerd, T. A. J. (1963): The Spleen and Anaemia, Brit. med. J.. ii, 517.

RIFKIND, R. A. (1964): Mechanisms of Sequestration in Heinz Body Anemia: An Electron Microscope Study, Blood, 24, 837.

Rothschild, M. A., Bauman, A., Yalow, R. S., and BERSON, S. A. (1954): Effect of Splenomegaly on Blood Volume, J. appl. Physiol., 6, 701.

Rowley, D. A. (1950a): The Effect of Splenectomy on the Formation of Circulating Antibody in the Adult Male Albino Rat, J. Immunol., 64, 289.

Rowley, (1950b): The Formation of Circulating Antibody in the Splenectomized Human Being Following Intravenous Injection of Heterologous Erythrocytes, J. Immunol., 65, 515.

TAliaferro, W. H., and TAliaferro, L. G. (1952) The Role of the Spleen and the Dynamics of Hemolysin Production in Homologous Anamnesis J. infect. Dis., 90, 205.

Verel, D. (1954): Observations on the Distribution of Plasma and Red Cells in Disease, Clin. Sci. 13, 51.

Weinstein, V. F. (1964): Haemodilution Anaemia Associated with Simple Splenic Hyperplasia, Lancet ii, 218.

Weiss, L. (1959): An Experimental Study of the Organization of the Reticuloendothelial System in the Red Pulp of the Spleen, J. Anat., 93, 465.

Wetherley-Mein. G., Jones, N. F., and Pullan, J. M. (1961): Effects of Splenectomy on Red Cell Production in Myelofibrosis, Brit. med. J., i, 84.

YouNG, L. E. (1955): Hereditary Spherocytosis, Amer. J. Med., 18, 486. 